ORGINAL ARTICLE

\title{
A Survey of Vitamin Intake amongst Hearing and Hearing- Impaired Female Students in Saudi Arabia: A Pilot Study
}

\author{
Susan Amin ${ }^{1,2^{*}}$ and Maha Al-Shammari ${ }^{2}$ \\ ${ }^{1}$ College of Medicine, University of Hail, Saudi Arabia \\ ${ }^{2}$ College of Medicine, RCSI Bahrain, Bahrain
}

*Corresponding author: Susan Amin, College of Medicine, University of Hail, Hail, Saudi Arabia; College of Medicine, RCSI Bahrain, P.O. Box 15503, Building No. 2441, Road 2835, Busaiteen 228, Bahrain, Tel: +97316660203

\begin{abstract}
Background: Previous international research shows severe vitamin deficiencies in people with hearing loss. Hearing loss is improved for many people when vitamins such as $A, B, C, D, E$ and $K$ are replaced.

Objective: To determine whether a dietary intake of vitamins linked to deafness were deficient among a group of 18-21 year-old hearing impaired and hearing Saudi Arabian female students.

Design: This was a cross sectional study involving 64 hearing students and 42 hard of hearing female students aged 18-21 in a university in Saudi Arabia. Food intake was assessed by a food frequency questionnaire. Vitamin levels were calculated for each food and compared to the recommended daily allowance (RDA) for each group. Knowledge and understanding of vitamin deficiency was answered by face to face interviews. The study duration was one year from September 2010 to September 2011.
\end{abstract}

Results: In comparing the vitamin amounts the students consumed over 24 hours for both groups, the hearing impaired group's vitamin consumption met the RDA. The hearing group's vitamin consumption met the RDA on all vitamins except for vitamin B9 and vitamin D. The RDA for vitamin B9 is $0.4 \mathrm{mg}$. The hearing group had an RDA of $0.3 \mathrm{mg}$. The RDA for vitamin $\mathrm{D}$ is $0.015 \mathrm{mg}$. The hearing group had an RDA of $0.01 \mathrm{mg}$. The hearing impaired group had a higher RDA overall with all vitamins compared to the hearing group.

A greater percentage of hearing students consumed a higher frequency of vitamin rich foods over the course of the week, compared to the hearing impaired students with values totalling $55 \%$ and $40 \%$ respectively.

Discussion: The vitamin $\mathrm{D}$ deficiency among the students could be attributed largely to poor exposure to sunlight, poor dietary vitamin D supplementation and obesity. The lower frequency of vitamin deficiency among the hearing students could be attributed to environmental or behavioural factors or being exposed to different foods. The greater consumption of vitamins $\mathrm{B} 3, \mathrm{C}, \mathrm{E}$ and $\mathrm{K}$ among the hearing impaired students will be beneficial in the long term for protection in noise induced hearing loss. Increasing antioxidants in the body to rid the body of free radicals. Increasing the activity of vitamin $\mathrm{D}$, an important vitamin in bone mineralization.

\section{Keywords}

Vitamins, Deafness, Northern Saudi Arabia, Students, Deficiency

\section{Introduction}

Hearing loss is a major public health problem and is expected to rise with the aging population. Roughly 360 million people around the world have some form of hearing loss and 32 million of these are children [1]. Dietary intake may play a role in the pathogenesis of many auditory disorders [2]. Deficiencies of several micronutrients have been associated with auditory dysfunction disorders in humans [3] and young growing animals [4]. International research has shown severe vitamin deficiencies in people with hearing dysfunctions including noise induced hearing loss [5-10], sensorineural hearing loss [11-14] antioxidant consumption [15] and calcium homeostasis imbalance [16-21]. Hearing loss improves when these missing vitamins $A, B, C, D, E$ and $K$ are replaced. This makes hearing loss caused by a deficiency in certain vitamins a problem that can be treated with good nutrition.

Citation: Amin S, Al-Shammari M (2020) A Survey of Vitamin Intake amongst Hearing and Hearing-Impaired Female Students in Saudi Arabia: A Pilot Study. Int J Womens Health Wellness 6:116. doi. org/10.23937/2474-1353/1510116

Accepted: November 17, 2020: Published: November 19, 2020

Copyright: (C) 2020 Amin S, et al. This is an open-access article distributed under the terms of the Creative Commons Attribution License, which permits unrestricted use, distribution, and reproduction in any medium, provided the original author and source are credited. 
The possible associations between poor vitamin A, $B, C, D$ and $E$ status with auditory dysfunction and protection, has not been widely studied and little attention has been given to the possible role of these micronutrients in hearing loss within certain age groups. The results of previous studies are inconsistent [22-26] possible reasons for this include dietary assessments being misclassified and not accounting for long term intake [26] and imprecise outcome measurements based on self-reports being used [25]. Furthermore, antioxidants may be most effective when working together with other nutrients.

The region of Hail, an area populated with highly consanguineous families and located $727 \mathrm{~km}$ north of Riyadh and $391 \mathrm{~km}$ South of Al Jouf, registers shortage in health care facilities compared to other regions in the Kingdom. However, no study was previously conducted in Hail in relation to vitamin intake and knowledge. In one study looking at vitamin D status in Saudi Arabia among one hundred and eighty people over the age of 18 in the Qassim region, the prevalence of Vitamin D deficiency/ insufficiency was found to be $67 \%$ [27].

Using a survey method, this study investigated intake of foods rich in vitamins A-K, and awareness of the necessity for these in hearing maintenance in a sample of Saudi female students both hearing and hearing impaired and to draw conclusions regarding their nutritional requirements.

\section{Methods}

\section{Subjects and study design}

This was a cross sectional study conducted at the department of special needs and the medical college, University of Hail, Kingdom of Saudi Arabia that assessed knowledge on vitamins and hearing loss and vitamin deficiency of the participants. Seventy five female hearing students (inclusion criteria was-10 to $15 \mathrm{~dB}$ frequency the normal hearing levels for the normal hearing students). Data obtained from university record.

Seventy five female hearing impaired students (The term "Hearing Impaired" is a description of someone who is hard of hearing or who has no hearing with general hearing loss. Inclusion criteria for this group is any hearing level perceived greater than $16 \mathrm{~dB}$ ) [28] Data obtained from university records.

A convenience sample of students were and invited to participate in the study involving dietary intake between September 2010 and September 2011. Students were recruited as they entered the college between the times of 8 am to 9 am. Hearing and hearing impaired student information was taken from their student records.

Students were included if they were in foundation year, had no underlying disease, were of Saudi origin and were not taking any vitamin supplements as well as meeting the requirement listed for hearing level. Of the students eligible to participate only 64 of the hearing female students and 42 of the hearing impaired female students gave their permission for the study and hence only these were included. Third- and fourth-year medical students involved in recruiting participants were trained in delivering a personal-assisted structured-interview prior to administering the questionnaire to participants. A special needs tutor with Arabic sign language interpreted for the hearing impaired participants. Awareness leaflets enclosing the common symptoms and signs of vitamin deficiency and its relation to hearing loss were provided after the completion of questionnaire.

\section{Ethical consideration}

Informed consent was obtained from participants prior to completing the questionnaires. The students made sure a full explanation of the study was provided to participants with the emphasis on the right of the subject not to participate or disclose information and confidentiality. Ethical approval was obtained from the local authorities as well as the University of Hail and the Medical College Council Committee, in compliance with the Helsinki Declaration [29].

\section{Tools for collecting data}

The questionnaire was first adapted and translated to Arabic based on published research about vitamin rich foods and consultation with an experienced dietician at the university [30] (Appendix 1) on results of deficiencies. For 40 of the food items, a serving size was described, using 'natural' units (such as one apple, a glass of milk, a slice of bread) whenever possible, or otherwise using typical serving sizes based on analyses of diet records (e.g, 1/2 cup of beans or 4-6 oz. (114-170 g) of meat as a main dish) (Appendix 2). Estimated portion sizes were used where possible according to published data on serving sizes [31,32]. The list of 40 foods was reduced to 13 by eliminating some items found to be infrequently used in a small pilot study. Subjects were asked to indicate for each food how often, on average, they had eaten the amount specified during the past week. Five multiple choice responses were possible, ranging from never to daily. Daily meaning consumption of food item every day. Two and three times a week indicate the food item was eaten a couple of times during the week. Rarely indicates occasionally and the never response indicates the student never ate the item. The amounts of vitamins in the foods were computed by multiplying the relative frequency that each food item was used (in this case once a day, daily would be equal to 1) By the nutrient content of the specified portion size, primarily using the united states department of agriculture food composition scores $[33,34]$ but supplemented with other published data and information with manufacturers when necessary [32]. 
Blood analysis to assess vitamin levels in the students was performed. However the parents of the students refused publication of these so these results are not included.

The section on the knowledge of the vitamin intake consisted of choice-type questions in a yes or no format in the design to elicit participant's knowledge in the main areas; knowledge of vitamin deficiency and symptoms and knowledge of the association of deafness with vitamin deficiency. Correct responses were given one point for choosing each: Food type and frequency while other options including "I do not know" were given nil.

A study identification number identified each respondent to ensure confidentiality of the information. Both descriptive and inferential statistics were used as fitting. Categorical data were expressed using frequencies, proportions, and percentages in SPSS. Chi square test of significance was used to report univariate analysis. A $p<0.05$ was applied as a level of significance for the survey questions and a one sided $T$ test of significance was used to compare the responses of the hearing students with those of the hearing impaired students.

\section{Results}

The ideal number of students was 75 hearing female students and 75 hearing impaired students. However upon receiving the surveys, only 64 female hearing students and 42 hearing impaired students gave their permission for the surveys, and hence only those are analysed here. All of the students were of Saudi Arabian origin and were between the ages of 18 and 21 (Table 1). Food frequency questionnaires completed for both the hearing impaired and the normal hearing group are in the appendix. The vitamin amounts were calculated for the 13 food items in the pilot study with items including peanuts, green vegetables, broccoli, peppers oranges, milk, eggs, bread, meat, fish, chicken, oats, and sunflower seeds.

In comparing the vitamin amounts the students consumed over 24 hours for the two groups, the hearing impaired group's vitamin consumption met the RDA. The hearing group's vitamin consumption met the RDA on all vitamins except for vitamin B9 and vitamin D. The RDA for vitamin $B 9$ is $0.4 \mathrm{mg}$. The hearing group had an RDA of $0.3 \mathrm{mg}$. The RDA for vitamin D is $0.015 \mathrm{mg}$. The hearing group had an RDA of $0.01 \mathrm{mg}$ (Table 2). The hearing impaired group had a higher RDA overall with all vitamins compared to the hearing group (Table 2 ).

A greater percentage of hearing students (Figure $1 A)$ had a higher frequency of vitamin intake over the course of the week, compared to the hearing impaired students (Figure 1B) with values of 28,13 and $14 \%$ (55\%) compared to 29,6 and $5 \%(40 \%)$ respectively. A lower percentage of hearing students (Figure $1 \mathrm{~A}$ ) never or rarely consumed the vitamin allowance compared to the hearing impaired group (Figure 1B) $9 \%$ versus $20 \%$ and $36 \%$ versus $40 \%$ respectively.

Table 1: Characteristics of participants.

\begin{tabular}{|l|l|l|}
\hline Females & Hearing group & Hearing impaired \\
\hline Number & 75 selected (64) in study & 75 selected (42) in study \\
\hline Nationality & Saudi Arabian & Saudi Arabian \\
\hline Age & $18-21$ & $18-21$ \\
\hline Diagnosis & -10 to $15 \mathrm{~dB}$ & Greater than $16 \mathrm{~dB}$ \\
\hline College division & Medical college & Special needs centre of college \\
\hline
\end{tabular}

Table 2: Absolute daily vitamin intake estimated from the food frequency questionnaires. $(P>0.05)$.

\begin{tabular}{|l|l|l|l|}
\hline Vitamin & $\begin{array}{l}\text { Estimated RDA of each vitamin in } \mathrm{mg} \\
\text { for the hearing students based on } \\
\text { intake of 13 listed foods }\end{array}$ & $\begin{array}{l}\text { Estimated RDA of each vitamin in mg } \\
\text { for hearing impaired students based on } \\
\text { intake of 13 listed foods }\end{array}$ & $\begin{array}{l}\text { Recommended daily } \\
\text { allowance of each vitamin } \\
\text { in mg }\end{array}$ \\
\hline A & 1.3 & 2.1 & 0.7 \\
\hline B1 & 1.2 & 1.8 & 0.8 \\
\hline B2 & 1.2 & 2.0 & 1.1 \\
\hline B3 & 17.9 & 28.4 & 14 \\
\hline B5 & 5.1 & 8.1 & 5 \\
\hline B6 & 1.4 & 2.6 & 1.2 \\
\hline B9 & 0.3 & 0.5 & 0.4 \\
\hline B12 & 6.3 & 10.1 & 0.0024 \\
\hline C & 145 & 230 & 75 \\
\hline D & 0.01 & 0.02 & 0.015 \\
\hline E & 16.3 & 26.0 & 15 \\
\hline K & 55.7 & 88.4 & 1 \\
\hline
\end{tabular}




\section{A (hearing students) and B (hearing impaired students).}
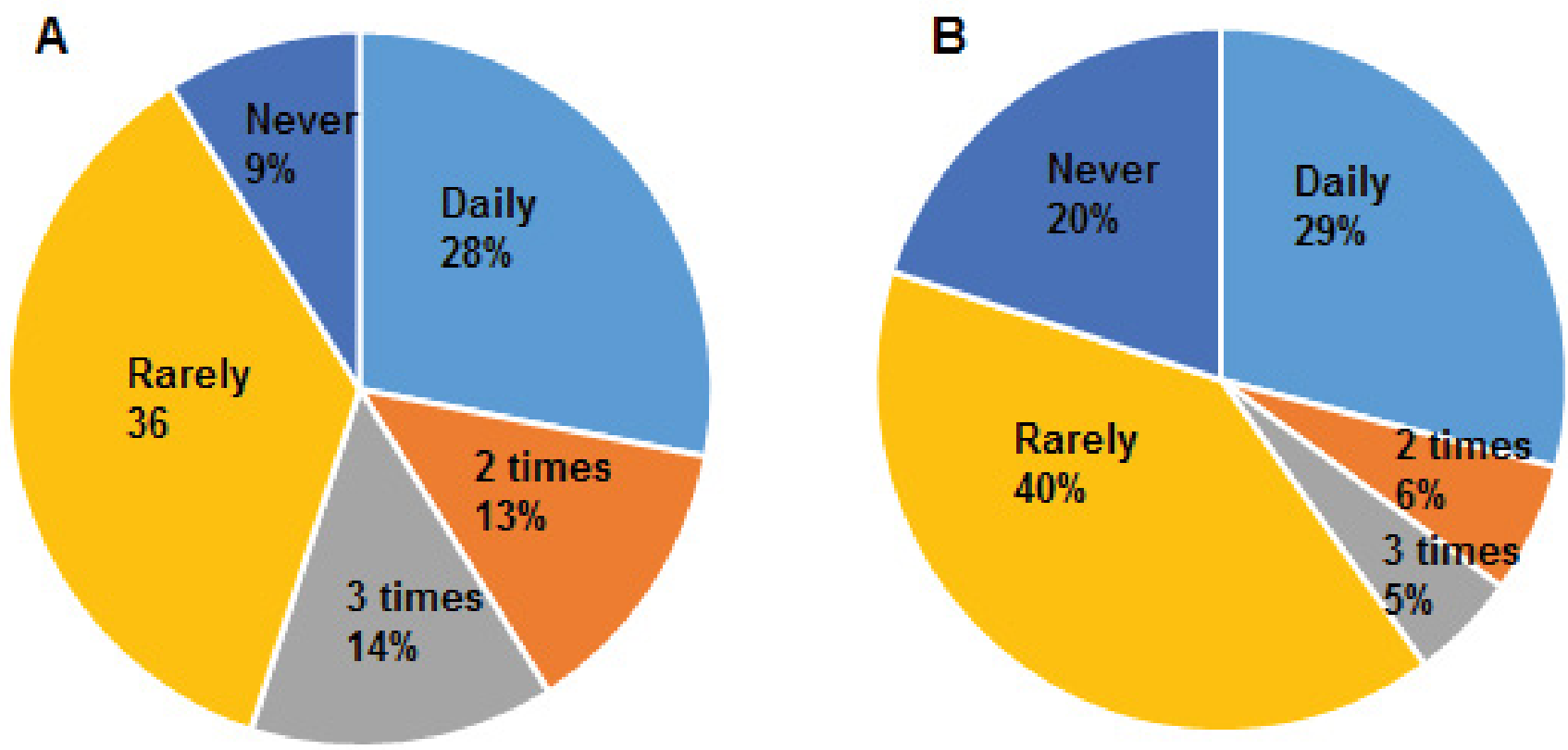

Figure 1: Frequency of vitamin consumption over a week for the hearing students $(A)$ and the hearing impaired students $(B)$. $P>0.05$

\section{Discussion}

The present study was addressed to look at the frequency of vitamin deficiency and awareness of vitamin deficiency and hearing loss among female hearing and impaired hearing students at the University of Hail, Saudi Arabia.

A food questionnaire was used to collect data on the RDA of vitamin consumption among the students.

Vitamin B3 had a higher consumption in the hearing impaired females compared to the hearing females.

A precursor to vitamin B3, NAD+ (Nicotinamide adenine dinucleotide) with its precursor NR (Nicotinomide riboside) act together to prevent hearing loss. They do this by increasing the activity of protein SIRT3 (sirtuin3) a protein which is involved in resistance to noise induced hearing loss. NR can be used alone to protect nerves that innervate the cochlea. Loud noise exposure can damage the synapses connecting the nerves and the hair cells in the cochlea, resulting in noise induced hearing loss. NR was successful at preventing damage to these synaptic connections regardless if it is given before or after noise exposure [35]. The higher consumption among this group may help in their protection against sensorineural hearing loss in the long term. Both groups also met the RDA allowance of vitamin B3 of 14 mg.

There was a higher consumption of vitamin $E$ and $C$ among the hearing impaired females compared to the hearing females. Vitamin $C$ is an antioxidant that is effective against a variety of reactive oxygen species, in- cluding superoxide and hydroxyl radicals that have been implicated in the etiology of noise-induced hearing loss (NIHL) [36]. Both groups also met their RDA allowance of vitamins $C$ and $E$ of 75 and $15 \mathrm{mg}$ respectively.

Not enough vitamin $D$ was taken on a daily basis among the hearing group of students. Vitamin $D$ is an important vitamin responsible for the growth of bones in the ear. There may be other factors that may also contribute to low vitamin D among the hearing students, such as the clothing where by the Muslim women surveyed in our study tended to wear clothes which apart from face and hands cover all other parts of their bodies. Even if they go out, opportunity to expose their bodies in sunlight is not available due to "Abaya/ Hijab" (a head to toe covering which only has small openings for the eyes) [37]. Even though there is an abundance of sunshine in Saudi Arabia it is extreme in certain months and women tend to stay inside their homes [38]. The skin colour in the Saudi population varies from light brown to dark. Dark pigmentation has been found to reduce the synthesis on the skin of vitamin $D$ because ultra violet light cannot reach the appropriate layer of the skin [39]. In future studies it would be of interest to investigate how much time the hearing students and the hearing impaired students spend outside.

The lack of vitamin $D$ intake among our students also coincides with a study conducted by King Abdul-Aziz University, Jeddah, where a total of 1,172 healthy Saudi women living in the Jeddah area were randomly selected and studied and $80 \%$ of the Saudi women studied exhibited vitamin $D$ deficiency. The study concluded that Saudi women have a high prevalence of vitamin $D$ 
deficiency and this is attributed largely to poor exposure to sunlight, poor dietary vitamin D supplementation and obesity [40]. Saudi impaired hearing students in one study were mainly at home and this was associated with a lack of UV-light [41].

Vitamin $\mathrm{K}$ was highly consumed among the hearing impaired students compared to the hearing students. Vitamin $\mathrm{K}$ works with vitamin $\mathrm{D}$ and may help its function in healthy bone growth for the ear.

Vitamin B-12 status may aid in neuron myelination in the cochlear nerve [14]. This also had a higher consumption among the hearing impaired students compared to the hearing students and may offer protection in sensorineural deafness.

The greater consumption of vitamins over the course of the week in the hearing group compared to the hearing impaired group could be due to having friendships outside the college and having an increased exposure to different foods. This coincides with one study which looked at friendships between hearing and hearing impaired students, the hearing students tended to mix with students from other disciplines, whereas the hearing impaired students in the university tended to mix with students from their class only $[42,43]$. These findings are also in agreement with previous studies on the relationship of general mixed friendship quality with wellbeing [44].

A higher consumption of vitamins may be linked to a compensatory affect whereby other nutrients in the diet may be deficient and others more to create a balance. More studies would be needed to test this. Further studies could also look at the effects of having excess vitamins for example too much vitamin $C$ can cause muscle cramps [3].

Symptoms of vitamin deficiency were looked at in surveys and the students reported no symptoms of vitamin deficiencies (results not shown).

An important strength of the study was the use of the translators that were able to help us converse with the hearing impaired female students. The student interviewers also had to make a number of trips to the special needs department to build up a rapport with the students and this helped immensely. This preliminary data will help immensely for future studies in effects of nutritional deficiency and deafness in Saudi Arabia.

An important limitation the authors faced were that they were unable to get results investigating the symptoms of vitamin deficiency for the hard of hearing group as the students were unable to understand the questions relating to this as well as some of the food names. The translator tried to show these fruits in sign language but it was not clear to the students. In terms of the hearing students, questions appeared straightforward once the student interviewers had translated these to Arabic. In both groups questions were simplified as much as possible, to enable all participants regardless of education level to read and answer the questions. Pictures alongside the Arabic translation may have helped and this will be used in future studies. Another limitation was that as this was a preliminary study power analysis was not used to assess sample size. In addition the number of declined participation was not recorded, and the data available from reluctant students may have shifted paradigm of the trends seen in the study. Our study only looked at females, further studies are required to compare the frequency of vitamin intake with males. One study reported men over 60 years of age and older may benefit from higher folate intake to reduce the risk of developing hearing loss [25]. Folic acid met the RDA for the students in this study. Another limitation is the method as one week cannot fully represent the usual dietary intake of the students. Next time we will employ one week data collection periods spaced according to account for seasonal as well as short term variability. In one study use of this promoted strong correlations with the questionnaires used [45].

The RDA of vitamin B9 was lower in the hearing group. B9 at moderate levels offers protection against lower hearing frequencies in relatively young adults; a finding consistent with that from a folic acid supplementation study in the Netherlands [46]. Workshops and education on the benefits of B9 supplementation could help this group in the long term.

\section{Conclusions}

In conclusion most students achieved the RDA for vitamin consumption. A greater percentage of hearing students consumed a higher frequency of vitamin rich foods over the course of the week, compared to the hearing impaired students with values totalling 55\% and $40 \%$ respectively. These differences could be attributed to environmental and behavioral factors. The hearing impaired female students had higher consumptions of $\mathrm{B} 3, \mathrm{C}, \mathrm{E}$ and $\mathrm{K}$ in their diets and these may give added protection in hearing loss.

Vitamin D and B9 were vitamins that did not meet the RDA for the hearing group and foods contained more dairy will help in this as well as supplemented foods with these vitamins or just taking multivitamins.

Workshops to educate the students and their families on vitamin supplementation, nutrition and hearing loss would be something for future studies.

\section{Acknowledgements}

We would like to thank the students for their assistance in this project in answering our questionnaires. We are deeply grateful for the University of Hail for funding this research.

\section{Conflict of Interests}

All authors declare no conflicts of interest. 


\section{Author Contributions}

SA wrote most of the paper and was the group leader for this project. MS wrote part of the paper and was involved in the analysis and collection of data.

\section{References}

1. WHO (2013) Millions of people in the world have hearing loss that can be treated or prevented. World Health Organization Geneva.

2. Sun AH, Wang ZM, Xiao SZ, LiZ J, Ding JC, et al. (1992) Idiopathic sudden hearing loss and disturbance of iron metabolism. A clinical survey of 426 cases. J Otorhinolaryngology Relate Spec 54: 66-70.

3. Roman GC (1994) An epidemic in cuba of optic neuropathy, Sensorineural deafness, peripheral sensory neuropathy and dorsolateral myeloneuropathy. J Neural Sci 127 11-28.

4. Buckmaster PS, Holliday TA, Bai SC, Rogers QR, et al (1993) Brainstem auditory evoked potential interwave intervals are prolonged in Vitamin- B-6-Deficient cats. J Nutr 123: $20-26$.

5. Evans P, Hallowell B (1999) Free radicals and hearing: Cause, consequence, and criteria. Ann NY Acad Sci 884: 19-40.

6. Frenz DA, Liu W, Cvekl A, Xie Q, Waseef LA, et al. (2010) Retinoid signaling in inner ear development: $A$ goldilocks phenomenon. Am J Med Genet A 152: 2947-2961.

7. Biesalski HK, Wellner U, Stofft E, Bässler KH (1985) Vitamin A deficiency and sensory function. Acta Vitaminol Enzymol 7: 45-54.

8. Biesalski HK, Wellner U, Stofft E, Bässler KH (1990) Vitamin A deficiency increases noise susceptibility in guinea pigs. J Nutr 120: 726-737.

9. Lefebvre PP, Malgrange B, Staecker H, Moonen G, Van de Water TR, et al. (1993) Retinoic acid stimulates regeneration of mammalian auditory hair cells. Science 260: 692695.

10. BrooksW, SantoshamM, NaheedA, GoswaniD, Wahed MA, et al. (2005) Effect of weekly zinc supplements on incidence of pneumonia and diarrhea in children younger than 2 years in an urban, Low-income population in bangladesh: Randomized controlled trial. Lancet 366: 999-1004.

11. Andres R, Hallfrisch J (1989) Nutrient intake recommendations needed for the older american. J Am Diet Assoc 89: 1739-1741.

12. Krumholz A, Weiss $H$, Goldstein $P$, Harris $K$, Howard $D$, et al. (1981) Evoked responses in vitamin B12 deficiency. Ann Neurol 9: 407-409.

13. Savage DG, Lindenbaum J (1995) Folate-cobalamin interactions. In: Bailey LB (edn) Folate in health and disease. New York: Marcel Dekker 237-286.

14. Thatcher A, Le Prell C, Miller J, Green G (2014) Acemg supplementation ameliorates progressive connexin 26 hearing loss in a child. Int J Pediatr Otorhinolaryngol 78: 563-565.

15. Brookes GB (1985) Vitamin D deficiency and otosclerosis. Otolaryngol Head Neck Surg 93: 313-321.

16. Attics J, Weisz G, Alma S, Shamar A, Wiener M, et al. (1994) Oral magnesium intake reduces permanent hearing loss induced by noise exposure. Am J Otolaryngol 15: 2632.
17. Dubray C, Alloui A, Bardin L, Rock E, Mazur A, et al. (1997) Magnesium deficiency induces an hyperalgesia reversed by the NMDA receptor antagonist MK801. Neuroreport 8: 1383-1386.

18. Milani D, Guidolin D, Facci L, Pozzan T, Buso M, et al. (1991) Excitatory amino acid-induced alterations of cytoplasmic free $\mathrm{Ca}^{2+}$ individual cerebellar granule neurons: Role in neurotoxicity. Journal of Neuroscience Research 28: $434-441$

19. NakamuraM, AbeS, GotoY, Chishaki A, Akazawa K et al. (1994) In Vivo assessment of prevention of white-noiseinduced seizure in magnesium-deficient rats by N-Methyl-D-Aspartate receptor blockers. Epilepsy Res 17: 249256.

20. Altura BM, Altura BT, Gebrewold A, Ising H, Gunther T, et al. (1992) Noise induced hypertension and magnesium in rats: Relationship to microcirculation and calcium. J Appl Physiol 72: 194-202.

21. Brookes GB (1983) Vitamin D Deficiency-a new cause of cochlear deafness. J Laryngol Otol 97: 405-420.

22. Gopinath B, Flood VM, McMahon CM, Burlutsky G, Spankovich C, et al. (2011) Dietary antioxidant intake is associated with the prevalence but not incidence of age-related hearing loss. J Nutr Health Aging 15: 896-900.

23. Romeo G, Giorgetti M (1985) Therapeutic effects of vitamin A associated with Vitamin $E$ In perceptual hearing loss. Acta Vitaminol Enzymol 7: 139-143.

24. Spankovich C, Hood LJ, Silver HJ, Lambert W, Flood VM, et al. (2011) Associations between diet and both high and low pure tone averages and transient evoked optoacoustic emissions in an older adult population-based study. J Am Acad Audiol 22: 49-58.

25. Shargorodsky J, Curhan SG, Eavey R, Curhan GC (2010) A prospective study of vitamin intake and the risk of hearing loss in men. Otolaryngol Head Neck Surg 142: 231-236.

26. Michikawa T, Nishiwaki Y, Kikuchi Y, Hosoda K, Mizutari K, et al. (2009) Serum levels of retinol and other antioxidants for hearing impairment among japanese older adults. J Gerontol A Biol Sci Med Sci 64: 910-915.

27. Naeem Z, Abdul Rahman A, Fawzy Khalil S, Hisham I, Shaukat $F$, et al. (2011) Vitamin $D$ status among population of qassim region, Saudi Arabia. Int J Health Sci (Qassim) 5: 116-124.

28. Clark JG (1981) Uses and abuses of hearing loss classification. Asha 23: 493-500.

29. (2013) World medical association declaration of helsinki ethical principles for medical research involving human subjects. Clinical Review And Education 310: 2191-2194.

30. Feskanich D, Rimm EB, Giovannucci EL, Colditz GA, Stampfer MJ, et al. (1993) Reproducibility and validity of food intake measurement from a semiquantitative food frequency questionnaire. J Am Diet Assoc 93: 790-796.

31. Hunter DJ, Sampson L, Stampfer MJ, Colditz GA, Rosner B, et al. (1988) Variability in portion sizes of commonly consumed foods among a population of women in the united states. Am J Epidemiol 127: 1240-1249.

32. Adams CF (1975) Nutritive Value of American Foods. Handbook No. Washington, DC: US Department of Agriculture, 456

33. Feeley RM, Criver PE, Watt BK (1972) Cholesterol Content of Food. J Am Diet Assoc 61: 134-149. 
34. USDA. Dietary guidelines for Americans 2005. Washington, DC: US Department of Health and Human Services and Department of Agriculture.

35. Brown KD, Maqsood S, Huang JY, Pan Y, Harkcom W, et al. (2014) Activation of SIRT3 by the NAD ${ }^{+}$precursor nicotinamide riboside protects from noise-induced hearing loss. Cell Metabolism 20: 1059-1068.

36. McFadden SL, Woo JL, Michalak N, Ding D (2005) Dietary Vitamin $\mathrm{C}$ supplementation reduces noise-induced hearing loss in guinea pigs. Hearing Research 202: 200-208.

37. Emmett SD, West KP Jr (2014) Gestational vitamin A deficiency: A novel cause of sensorineural hearing loss in the developing world. Med Hypotheses 82: 6-10.

38. Sedrani SH, Al-Arabi K, Abanmy A, Elidrissy A (1992) Vitamin D Status of saudis, II. Effect of regional and environmental location. Saudi Med J 13: 206-213.

39. Holick MF (2006) High prevalence of Vitamin D inadequacy and implications for health. Mayo Clin Proc 81: 353-373.

40. Lips P (2006) Vitamin D physiology. Progress In Biophysics And Molecular Biology 92: 4-8.
41. Ardawi MS, Qari MH, Rouzia AA, Reddadi RM, AA Maimani, et al. (2011) Vitamin D status in relation to obesity, bone mineral density, bone turnover marker and vitamin D receptor genotypes in Saudi per-postmenopausal women. Osteoporosis Int 22: 463-475.

42. Blom H, Marshark M, Vervloed MPJ, Knorrs H (2014) Finding friends online: Online activities by deaf students and their well-being. PLoS One 9: 1-10.

43. Al-Shammari M, Ashankyty A, Al-Mowina N, Al-Mutairy N, Al -Shammari L, et al. (2014) Social-emotional perceptions of deaf students in hail, Saudi Arabia. American Journal of Educational Research 2: 304-315.

44. Kingery JN, Erdley CA, Marshall KC (2011) Peer acceptance and friendship as predictors of early adolescents' adjustment across the middle school transition. Merrill Palmer 57: $215-243$

45. Willett WC, Sampson L, Stampfer MJ, Rosner B, Bain C, et al. (1985) Reproducibility and validity of a semi quantitative food frequency questionnaire. Am J Epidemiol 122: 51-65.

46. Durga J, Verhoef $P$, Anteunis LJ, Schouten E, Kok FJ, et al. (2007) Effects of folic acid supplementation on hearing in older adults: A randomized, controlled trial. Annals of Internal Medicine 146: 1-9. 
Appendix 1: Food frequency data for the hearing impaired students 13 food stuffs.

Food frequency questionnaire results for the female hearing impaired students. Each first column is the frequency. Each row denotes the food item consumed. The second column denoted by the ${ }^{*}$ is the percentage change.

\begin{tabular}{|c|c|c|c|c|c|c|c|c|c|c|}
\hline $\begin{array}{l}\text { How often do } \\
\text { you eat these } \\
\text { food }\end{array}$ & daily & $\begin{array}{l}\text { Percentage } \\
\text { change }^{*}\end{array}$ & $\begin{array}{l}2 \text { times } \\
\text { a week }\end{array}$ & $\begin{array}{l}\text { Percentage } \\
\text { change }^{*}\end{array}$ & $\begin{array}{l}3 \text { times a } \\
\text { week }\end{array}$ & $\begin{array}{l}\text { Percentage } \\
\text { change }^{*}\end{array}$ & rarely & $\begin{array}{l}\text { Percentage } \\
\text { change }^{*}\end{array}$ & never & $\begin{array}{l}\begin{array}{l}\text { Percentage } \\
\text { change }^{*}\end{array} \\
\text { a }\end{array}$ \\
\hline $\begin{array}{l}1 / 2 \text { cup of } \\
\text { peanuts, } 146 \\
\text { grams }\end{array}$ & 11.0 & 13.3 & 4.0 & 4.4 & 1.0 & 1.2 & 33.0 & 39.3 & 3.0 & 3.6 \\
\hline $\begin{array}{l}1 / 2 \text { cup of } \\
\text { green veg, } \\
146 \text { grams }\end{array}$ & 5.0 & 5.7 & 0.0 & 0.0 & 0.0 & 0.0 & 0.0 & 0.0 & 0.0 & 0.0 \\
\hline $\begin{array}{l}1 \text { serving of } \\
\text { fruit such as } \\
\text { an orange }\end{array}$ & 3.0 & 3.4 & 0.0 & 0.0 & 0.0 & 0.0 & 0.0 & 0.0 & 0.0 & 0.0 \\
\hline $\begin{array}{l}1 / 2 \text { cup of } \\
\text { peppers, } 92 \\
\text { grams sliced }\end{array}$ & 20.0 & 24.1 & 2.0 & 2.4 & 1.0 & 1.2 & 14.0 & 16.9 & 15.0 & 18.1 \\
\hline $\begin{array}{l}1 / 2 \text { cup of } \\
\text { broccoli, } 92 \\
\text { grams }\end{array}$ & 6.0 & 7.2 & 1.0 & 1.2 & 2.0 & 2.4 & 16.0 & 19.3 & 29.0 & 34.3 \\
\hline $\begin{array}{l}\text { Glass of milk, } \\
244 \mathrm{~g}\end{array}$ & 22 & 26.5 & 7.0 & 8.4 & 3.0 & 3.6 & 20.0 & 24.1 & 5.0 & 6.0 \\
\hline $\begin{array}{l}1 \text { eggs } 46 \\
\text { grams }\end{array}$ & 14.0 & 16.9 & 1.0 & 1.2 & 3.0 & 3.6 & 17.0 & 20.5 & 4.0 & 4.8 \\
\hline $\begin{array}{l}1 \text { slices of } \\
\text { wheat bread, } \\
46 \text { grams }\end{array}$ & 1.0 & 1.1 & 0.0 & 0.0 & 0.0 & 0.0 & 0.0 & 0.0 & 1.0 & 1.1 \\
\hline $\begin{array}{l}114 \text { to } 170 \mathrm{~g} \\
\text { of meat }\end{array}$ & 20.0 & 24.1 & 2.0 & 2.4 & 3.0 & 3.6 & 20.0 & 24.1 & 5.0 & 6.0 \\
\hline $\begin{array}{l}114 \text { to } 170 \mathrm{~g} \\
\text { of fish }\end{array}$ & 2.0 & 2.4 & 3.0 & 3.6 & 4.0 & 4.8 & 26.0 & 31.3 & 11.0 & 13.3 \\
\hline $\begin{array}{l}114 \text { to } 170 \mathrm{~g} \\
\text { of chicken }\end{array}$ & 37.0 & 44.6 & 3.0 & 3.6 & 5.0 & 6.0 & 7.0 & 8.4 & 1.0 & 1.2 \\
\hline $\begin{array}{l}1 / 2 \text { cup of oats, } \\
92 \text { grams }\end{array}$ & 10.0 & 12.0 & 4.0 & 4.8 & 6.0 & 6.2 & 25.0 & 30.1 & 20.0 & 24.1 \\
\hline $\begin{array}{l}1 / 2 \text { cup of } \\
\text { sunflower } \\
\text { seeds, } 92 \\
\text { grams }\end{array}$ & 4.0 & 4.8 & 4.0 & 4.8 & 2.0 & 2.4 & 34.0 & 41.0 & 13.0 & 15.7 \\
\hline
\end{tabular}


Appendix Table 2: Food frequency data for the hearing students 13 items.

Food frequency questionnaire results for the female hearing students. Each first column is the frequency. Each row denotes the food item consumed. The second column denoted by the ${ }^{*}$ is the percentage change.

\begin{tabular}{|c|c|c|c|c|c|c|c|c|c|c|}
\hline $\begin{array}{l}\text { How often } \\
\text { do you eat } \\
\text { these food }\end{array}$ & daily & $\begin{array}{l}\text { Percentage } \\
\text { change }^{*}\end{array}$ & $\begin{array}{l}2 \text { times } \\
\text { a week }\end{array}$ & $\begin{array}{l}\text { Percentage } \\
\text { change }^{*}\end{array}$ & $\begin{array}{l}3 \text { times } \\
\text { a week }\end{array}$ & $\begin{array}{l}\text { Percentage } \\
\text { change }^{*}\end{array}$ & rarely & $\begin{array}{l}\text { Percentage } \\
\text { change }^{*}\end{array}$ & never & $\begin{array}{l}\text { Percentage } \\
\text { change }^{*}\end{array}$ \\
\hline $\begin{array}{l}1 / 2 \text { cup of } \\
\text { peanuts, } \\
146 \text { grams }\end{array}$ & 0.0 & 0.0 & 1.0 & 2.3 & 1.0 & 2.3 & 27.0 & 62.8 & 10.0 & 23.3 \\
\hline $\begin{array}{l}1 / 2 \text { cup of } \\
\text { leafy green } \\
\text { veg, } 146 \\
\text { grams }\end{array}$ & 0.0 & 0.0 & 1.0 & 2.3 & 0.0 & 0.0 & 18.0 & 41.9 & 10.0 & 23.3 \\
\hline 1 orange & 14.0 & 32.6 & 6.0 & 14.0 & 12.0 & 27.9 & 8.0 & 18.6 & 0.0 & 0.0 \\
\hline $\begin{array}{l}1 / 2 \text { cup of } \\
\text { peppers, } \\
92 \text { grams }\end{array}$ & 10 & 23.3 & 6.0 & 14.0 & 4.0 & 9.3 & 16.0 & 37.2 & 4.0 & 9.3 \\
\hline $\begin{array}{l}1 / 2 \text { cup of } \\
\text { broccoli, } \\
92 \text { grams }\end{array}$ & 6.0 & 14.0 & 1.0 & 2.3 & 1.0 & 2.3 & 23.0 & 53.5 & 5.0 & 11.6 \\
\hline $\begin{array}{l}\text { Glass of } \\
\text { milk, } 244 \\
\text { grams }\end{array}$ & 20 & 46.5 & 5.0 & 11.6 & 6.0 & 14.0 & 9.0 & 20.9 & 0.0 & 0.0 \\
\hline $\begin{array}{l}1 \text { egg, } 46 \\
\text { grams }\end{array}$ & 14 & 32.6 & 5.0 & 11.6 & 8.0 & 18.6 & 9.0 & 20.9 & 1.0 & 2.3 \\
\hline $\begin{array}{l}1 \text { slices of } \\
\text { bread, } 46 \\
\text { grams }\end{array}$ & 33.0 & 76.7 & 3.0 & 7.0 & 2.0 & 4.7 & 2.0 & 4.7 & 1.0 & 2.3 \\
\hline $\begin{array}{l}114 \text { to } 170 \\
\mathrm{~g} \text { of meat }\end{array}$ & 10.0 & 23.3 & 9.0 & 20.9 & 9.0 & 20.9 & 9.0 & 20.9 & 3.0 & 7.0 \\
\hline $\begin{array}{l}114 \text { to } 170 \\
\mathrm{~g} \text { of fish }\end{array}$ & 8.0 & 18.6 & 11.0 & 25.6 & 7.0 & 16.3 & 10.0 & 23.9 & 3.0 & 7.0 \\
\hline $\begin{array}{l}114 \text { to } 170 \\
g \text { of chick- } \\
\text { en }\end{array}$ & 12.0 & 27.9 & 4.0 & 9.3 & 4.0 & 9.3 & 9.0 & 20.9 & 3.0 & 7.0 \\
\hline $\begin{array}{l}1 / 2 \text { cup of } \\
\text { oats, } 92 \\
\text { grams }\end{array}$ & 4.0 & 9.3 & 8.0 & 18.6 & 10.0 & 23.3 & 15.0 & 34.9 & 0.0 & 0.0 \\
\hline $\begin{array}{l}1 / 2 \text { cup of } \\
\text { sunflower } \\
\text { seeds, } 92 \\
\text { grams }\end{array}$ & 3.0 & 7.0 & 4.0 & 9.3 & 2.0 & 4.7 & 20.0 & 46.5 & 6.0 & 14.0 \\
\hline
\end{tabular}

